\title{
ECO-DISTRIBUTION CENTRES FOR AGRICULTURAL PRODUCTS IN THE FUNCTION OF CONSUMER POTENTIAL OF URBAN CENTRES
}

\author{
Marko Šundov ${ }^{6}$, Dušanka Gajdić ${ }^{7}$ \& Kristina Petljak ${ }^{8}$
}

UDC / UDK: 641.3:631.147:658.89:911.375

JEL classification / JEL klasifikacija: Q1, Q57, R, D12

DOI: https://doi.org/10.22598/pi-be/2019.13.2.53

Original scientific paper / Izvorni znanstveni rad

Received / Primljeno: October 2, 2019 / 2. listopada 2019.

Accepted for publishing / Prihvaćeno za tisak: November 20, 2019 / 20.

studenog 2019.

\section{Summary}

Spatial expansion and increasing population of cities is turning them into neuralgic points of the food supply chain. Due to its structure and the speed of life processes, food is delivered to urban centres through conventional supply chains, and therefore, today we are faced with an extremely dependent consumer (due to the lack of food self-supply). For this reason, the strategic development of cities requires sustainable thinking and reasoning when it comes to food supply. A simple possible solution for the continuous and sustainable supply for the urban population is the development of ecodistribution centres for agri-food products. With the implementation of this model, numerous effects can be achieved; developing the rural environment of cities reduces the pressure of population inflows; ensuring the supply of fresh, high-quality food in

* Paper presented at International Scientific Conference „,TRADE PERSPECTIVES 2019: Business model innovations in domestic and international trade", November 2829, 2019, Zagreb, Croatia. Abstract of paper published in Conference Proceedings.

6 Marko Šundov, Ph.D., Stano-uprava d.o.o., Split, Croatia, E-mail: markosundov2@gmail.com.*corresponding author

${ }^{7}$ Dušanka Gajdić, Spec. M. Sc. Econ., Senior lecturer, Križevci College of Agriculture, Križevci, Croatia, E-mail: dgajdic@vguk.hr

${ }^{8}$ Kristina Petljak, Ph.D., University of Zagreb, Faculty of Economics \& Business Zagreb, Department of Trade and International Business, Zagreb, Croatia, E-mail: kpetljak@efzg.hr 
sufficient amounts for the whole population, sustainable management of the waste generated in the process of food distribution and use. The short agri-food chain management, i.e. its production and consumption capacities, considerably reduces dependence on conventional chains. At the same time, prerequisites are created for controlling the production and disposal of waste within agri-food supply chains. Therefore, in this paper, we analyse the consumer potential of urban centres as the fundamental determinant for designing and implementing eco-distribution centres for agricultural products. Empirical research on consumer potential in urban centres was conducted with the help of two utility companies in the city of Split, in 20 residential buildings, and 148 tenants participated in the study.

Key words: eco-distribution centre, short agri-food chains, urban centres, consumer potential, empirical research

\section{INTRODUCTION}

Food supply chains have become a necessity for everyone because food reaches all consumers through food supply chains. For both local and international chains, availability of a sufficient amount of high-quality food on time should be the main purpose of any food supply chain, regardless of its structure and length. At the same time, food distribution generates significant amounts of waste because food needs to be protected during logistic and transport activities. The largest portion of food waste along the food supply chain is generated at the final consumption stage, which is also the final stage of the food supply chain. This implies food loss generated by end users in households or businesses, such as restaurants or catering facilities. This causes additional problems for urban centres, since in addition to exceptional dependency on the continuous delivery of food from different and remote places (global distribution), issues arise due to enormous quantities of waste which has to be disposed. Being aware of this, developed social systems continually work to establish sustainable waste management processes. Additionally, awareness of the need to revitalise rural areas through urban-rural partnership projects has increased, which also decreases the level of dependency on food distribution, as well as waste generation as the consequence of all processes in food supply chains. One of the possible solutions to this problem is the establishment of ecodistribution centres of short supply chains.

An eco-distribution centre is a Short Food Supply Chain (SFSC) model for fresh agri-food products that has the potential to meet the growing demand of the urban population for home-grown, local food while also bringing environmental benefits through organised food waste disposal at the local level (Šundov \& Gajdić, 2019). This 
refers to creating an Alternative Food Network (AFN) or Food Hubs (FH). AFNs have certain basic features which include the following: social cooperation and partnership between producers and consumers, the capability to re-connect production and consumption using sustainable models, the ability to stimulate local markets with regional identity and re-aggregate value in the circulation of quality and differentiated products, for example, organic (Gajdić, 2019). A food hub is an intermediary organisation or a company that offers a logistic and organisational platform for collecting and distributing authentic agricultural and food products of local and regional producers to wholesale customers (hospitals, schools and other institutions, restaurants, hotels, etc.) and end consumers (individuals and/or groups) (Berti \& Mulligan, 2016). Ubrežiová et al. (2015) have highlighted the importance of alternative networks in activating local human resources and local sources, which can support the strengthening of local social ties.

Managing the food chain flow, i.e. the development of own production and consumption capacities, has a dual effect: it enables significant reduction of dependency on corporate food chains and also creates prerequisites for production control and waste disposal within the food supply chains. Both effects directly affect the long-term sustainable development of a certain micro-location. It is a fact that starting up and establishing such supply chains requires certain resources and joint actions of several stakeholders. That is why empirical research is required for successful development of this form of SFSC to determine whether the main stakeholders have the same attitude towards this idea.

The subject and aim of this research is to analyse the capacities and motivation of consumers to become involved in this form of a short supply chain, their needs and especially their perception regarding food waste disposal. The second part of the paper describes the empirical research conducted on the sample of 148 participants, on the purchase and consumption of fresh food products, consumer preferences in the food purchase, with the aim of designing an eco-distribution centre to supply urban population with fresh food products.

\section{URBAN-RURAL PARTNERSHIPS}

The increasing tendency towards urbanisation threatens to create overcrowded environments where various problems occur. Integration of an urban system with a rural surrounding and coordinating different mutually dependent processes presents a challenge which the economy of the $21^{\text {st }}$ century should address. Today, urban-rural partnership is developing beyond the one-way exchange. More complex, dynamic, intertwined interdependencies are evolving that shape the wealth of cities and villages. 


\subsection{Definition of urban-rural partnerships}

Cities and their strategies are increasingly becoming new protagonists in terms of shaping the urban population's nutrition strategy and other areas related to food, especially food loss and food waste disposal (Šundov \& Gajdić, 2019). Local agriculture supports the economies of the city, since farmland around cities is an ideal place for production, and urban centres for the sale of home-grown, locally produced food (Svržnjak et al., 2018).

Urban-rural partnerships add an important dimension to understanding key issues of regional development and forming efficient policies for their solving (Davoudi $\&$ Stead, 2002). The term 'urban-rural partnership' expresses what this type of cooperation is striving for: uniting for growth and innovation in urban and rural areas and assuming shared responsibility for their future. Urban-rural partnerships can develop through a variety of social and economic activities. Before choosing the direction of development of an urban-rural partnership model, micro-location to which it will apply should be analysed, which requires certain tools (known and to be developed during the analysis process). In this case, micro-location means smaller urban areas within large cities which, if connected in terms of space and infrastructure, may respond more effectively and efficiently to the needs of the local population in today's globalised world. Some of the potential factors which influence the development of urban-rural partnerships are: agriculture, science, culture, energy, traffic infrastructure, socio-demographic indicators of a certain area, etc. All of the above mentioned have the potential which may be determined by a variety of activities and processes which may impact the area and the direction of urban-rural partnership development.

Some of the benefits of urban-rural partnerships are strengthening and expansion of local resources to achieve sustainable food value chains; active offering of rural area resources (family farms - FF) to urban population; strengthening of the position of family farms; improvement of living conditions in a certain urban location and sustainable waste and environment management, etc. One of the key benefits which would be gained by establishing urban-rural partnerships is shortening of the food distribution chain, i.e. reduction of the distance between production and consumers (Šundov \& Gajdić, 2019).

The organisational structure of an urban-rural partnership has to meet the requirements of all stakeholders as well as general terms of a certain local community. Civic engagement and participation are increased when people have strong ties to their communities (Albanesi et al., 2007; Perkins et al., 2002), and commitment to the community also increases the individual's willingness to participate in different collaborative systems (Brehm et al., 2006). 


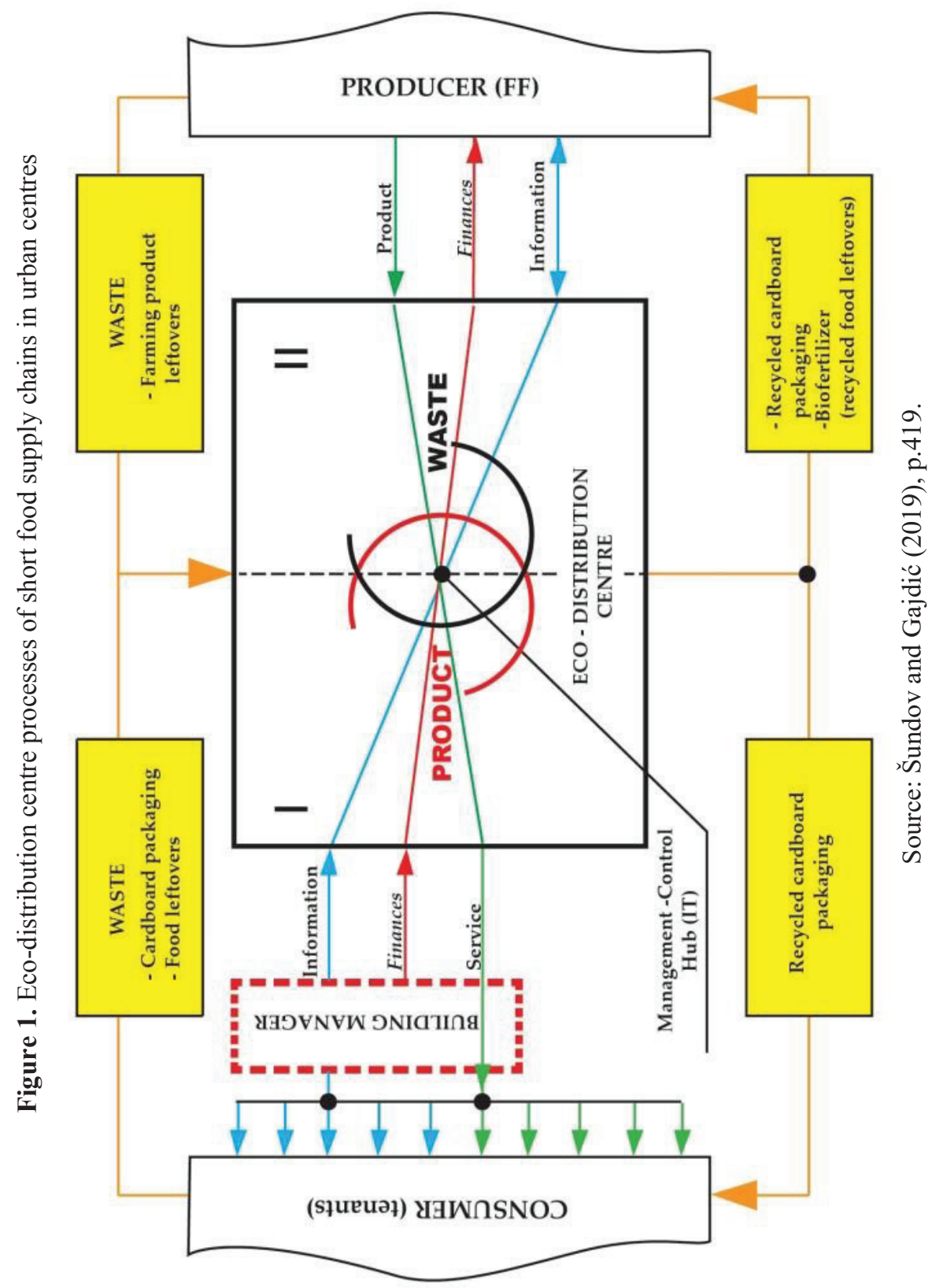




\subsection{Eco-distribution centres as a type of food hubs}

Mass, i.e. corporate food production is becoming the lead polluter and threat to the sustainable development, whether it is its immediate production, its distribution to the end user, or disposal after use. Accumulation of these adverse effects of the existing food chain is further accelerated by the large population growth. One way to slow down this negative trend and achieve balance that would allow nature sufficient time to self-repair is to restore food production and consumption in the micro-community.

In the paper Šundov and Gajdić (2019) show the development of a theoretical model of eco-distribution of agri-food products in urban centres which also enables waste management and creates prerequisites for balanced and sustainable development of a certain area through the establishment of urban-rural partnerships (Figure 1).

Main stakeholders involved in this form of SSC would be agricultural producers, i.e. family farms (FF), consumers, i.e. tenants of a certain urban area, and managers of several residential buildings that would play a key role in the bidirectional communication process and the flow of customer-distributor-producer information. The main idea behind an eco-distribution centre is that it functions as a closed loop and, as part of its service process, contains a waste processing zone for the waste from the use of agricultural and food products. By creating a closed loop, the use of products is maximised, and the reversibility (recoverability) effect significantly affects the cost-effectiveness of the whole process.

As shown in Figure 1, an eco-distribution centre has two zones: Zone I contains a logistic distribution centre where received orders (see information flow) are used to sort and prepare product placements from the producer (FF) to the end customer (tenants of several residential buildings). Zone I is the central place for logistics distribution activities towards the customer, and it is essential for establishing effective and efficient green food networks. Zone II is a supplement to the logistics distribution centre, where reversible activities, i.e. return activities take place. In this zone, there are two subzones: the zone for the collection and processing of cardboard packaging and the zone for the collection and recycling of food leftovers into biofuel. A very important role in successful functioning of this centre is played by the management and control hub which is the 'control brain' of the whole system, based on IT solutions due to the complexity of the network itself (more in Šundov \& Gajdić, 2019).

The first step in implementing this concept would be to define main urban centres with the 'ring' of influence, based on which an analysis would be carried out, and directions for further activities defined. From the outset, it is important that all stakeholders show their willingness and interest in this form of collaboration, in recognizing common goals and benefits for each individual and for the entire local community. That would create prerequisites for balanced development based on natural 
conditions without imposing solutions through development plans created outside of the environment to which they refer.

\section{CONSUMER SIDE OF THE SUPPLY CHAIN}

The food supply chain consists of five stages (agricultural production, storing and handling, processing, distribution and consumption). Each of these stages involves wasting food, i.e. food loss and generation of food waste. Numerous studies (Blondin et al., 2014; Costello et al., 2015; Gustavsson et al., 2011; Govindan, 2018; Liljestrand, 2017; Lipinski et al., 2013; Parfitt et al., 2010; Quested et al., 2013; Stangherlin \& de Barcellos, 2018) have shown that the largest portion of waste in the food supply chain is generated at the final consumption stage. Important factors affecting consumer food waste are divided into three categories: social factors, personal factors and behavioural factors (Stangherlin \& de Barcellos, 2018). Quested et al. (2013) analysed two possible directions for reducing household waste: influencing consumer behaviour which creates waste or changing the food-buying habits. Govindan (2018) analysed drivers and barriers to sustainable consumption and production in food supply chains.

\subsection{Food loss and food waste}

Food loss is frequent in every food supply chain. It occurs at the stages of production, storage and processing. According to Parfitt et al. (2010), food loss is the decrease in edible food mass in the supply chain intended for human consumption. Knežević et al. (2017, p. 153) point out that food loss 'occurs at the stages of production, storage, processing and physical distribution as an unwanted consequence of business processes or technical limitations in storing, infrastructure, packaging or marketing activities'.

Food waste means food loss at the end of the food supply chain, i.e. in retail and final consumption (catering establishments and households). Food waste usually occurs as a consequence of conscious behaviour by both retailers and consumers (Parfitt et al., 2010). According to Lipinski et al. (2013), food waste means food which is suitable for consumption and of adequate quality, but is not consumed. The consequence of nonconsumption of such food is its throwing away before or after it goes bad. According to Buzby et al. (2014), food loss is defined as the amount of edible food available for human consumption, but which is not consumed for some reason, while food waste is defined as edible food which is not consumed because of some human factors and actions.

The largest portion of food waste in the food supply chain is generated at the final consumption stage. Food waste at the final consumption stage, which is also the 
final stage of the food supply chain, implies food loss generated by end users in households or businesses, such as restaurants or catering facilities. Therefore, food waste at the final consumption stage includes edible food products which are discarded due to reduced quality, food which is purchased, but not prepared for consumption, and food which is prepared for consumption, but not consumed (Lipinski et al., 2013).

The amount of food thrown away every day is enormous, which is evident from the data of the Food and Agriculture Organization (FAO) of the United Nations. According to their estimate, approx. 1.3 billion tonnes of food for human consumption is wasted or thrown away every year. Food is thrown away in all stages of the food supply chain (Bloom, 2011), from the initial agricultural production to final consumption in households. Food thrown away also pollutes the environment (Royte, 2016). In the developed countries, the largest portion of food is thrown away at the end of the supply chain, i.e. at the final consumption stage. On the other hand, in the developing countries, food loss and food waste usually occur at the initial stages of the supply chain (FAO, 2011). In the European Union (EU), in 2012, food loss and food waste amounted to approx. 88 million tonnes, i.e. 173 kilos of food waste per person. The majority of food waste is generated in households and processing. In 2012, the household sector in the EU generated approx. 47 million tonnes of food waste.

According to the data of the Croatian Agency for the Environment and Nature (HAOP), almost 400000 tonnes of food waste, i.e. 97 kilos of food waste per person, was generated in 2017 in the Republic of Croatia. As at the EU level, the majority of waste in the Republic of Croatia was generated in the household sector, as much as $77 \%$. Comparing that data to the EU average, which is 92 kilos of food waste per person, it is evident that the Republic of Croatia is below average. It was determined that household income significantly affects the amount of household waste. Households with higher income buy fewer food products of higher quality, while households with lower income buy more food products of lower quality. Therefore, households with higher income generate less food waste than households with lower income. Furthermore, often households with higher income cook less frequently, which results in less food that is thrown away (HAOP, 2018). As numerous organisations and countries are trying to reduce food waste, the Republic of Croatia is also trying to act in this regard. So, the Program for Implementation of the Plan for Prevention and Reduction of Food Waste in the Republic of Croatia 2019-2022 was adopted. It is the first comprehensive document in the Republic of Croatia to contain measures aimed at reducing food waste. The purpose of the program is to improve legislation, establish a system for prevention of waste generation, re-direct the surplus of food, exchange information, and motivate citizens to handle food responsibly. 
In addition to the fact that food is sensitive to various conditions, companies dealing with production and distribution of highly perishable food are facing additional requirements. When dealing with this type of product, it is necessary to ensure the shortest possible time of flow through the supply chain (Zhong et al., 2017). Liljestrand (2017) points to the importance of time management and information management in achieving a sustainable way of operating the food supply chain. She notes that it is crucial to distribute time evenly in the supply chain, thus striving to reduce food waste, which is essential for enhancing the sustainability of the supply chain.

In order to successfully reduce food waste at the final consumption stage, consumer behaviour needs to be considered during the food supply process.

\subsection{Motives and habits of fresh food products purchase and consumption}

Motives influence consumer behaviour very often. It is difficult to discover consumer motives because they are frequently driven by emotions, which are unpredictable. Consumers are driven by positive and negative motives. Positive motivation encourages them to purchase certain products or services, while negative motivation acts as a deterrent. Motives are often linked to needs, goals and impulses; however, the difference between these terms is obvious, so it can be argued that needs are the true source of motives because they present a lack, i.e. an absence in a person's body, as well as their mind. It can be said that motives are the internal factors that make us act, but they also direct and govern our actions (Kesić, 2006).

In the developed countries there is a growing number of aware consumers who consciously manage their consumption and make careful food purchasing decisions. Apart from a satisfying flavour, appearance and price, consumers expect food to have positive effects on their health, while their lifestyles and eating habits dictate what they will buy and when they will buy it (Gajdić et al., 2019). The factors affecting consumer behaviour when purchasing and consuming food can be: biological, economical, sociological, demographic and psychological (Krešić, 2012).

There are a number of important factors that encourage consumers to buy or not to buy products in SSCs. Those factors can be food quality, cost, lifestyle, supporting local economic growth, etc. According to Kovačić (2005) the most important consumer motives for direct purchase of agri-food products are: product freshness, application of traditional technological procedures, higher level of quality, distinctiveness of locally produced specialties, production and processing information, personal contact with the producer, mutual trust and visibility of the production process, as well as the purchasing atmosphere. In terms of quality, products purchased through SSCs are considered to be fresh because they are distributed directly from the place of production to the consumer. Another leading factor motivating consumers to buy locally produced foods is lifestyle 
(Arsil et al., 2014). Since they are a part of this system, consumers believe they can support their local farming families and the development of small enterprises in order to improve the local economy (Arsil et al., 2014). Research (Giampietri et al., 2016) has shown that the most significant attitudes that predict the purchase intention in short food supply chains are sustainability, convenience and personal consumer satisfaction.

According to Zoll et al. (2018), and based on different combinations of motivations and different motivation priorities, it is possible to identify three types of consumers in the AFN:

1) Lifestyle-oriented pragmatists focused on recreation and health. The key factors for them are gardening activities and tasty and healthy food, whereas sociological or ecological reasons are not that relevant.

2) Community-oriented conscious consumers who try to establish a relationship with producers and other consumers. They see the AFN as a community of solidarity between people who share similar values and they see their participation as a way to support the alternative food supply.

3) Persuasive practitioners group opposing the globalized agri-food systems and the perceived societal and environmental consequences. Hence, they interpret their participation in the AFN as a sign of protest and as a part of their sustainable lifestyle.

It is not possible to easily and exactly evaluate food quality and safety during and/or after the purchase. That is why consumers often assess food quality and safety based on the visual features of the food, such as the appearance, smell, flavour. Attributes such as 'local', 'of known origin' or 'agricultural products' are vital when a consumer has to make a purchase decision, especially one in relation to fresh fruit and vegetables (Gajdić et al., 2019). Migliore et al. (2015) believe that one of the main reasons why consumers are interested in SFSC are quality problems. Consumers notice numerous advantages of buying and consuming locally grown / home grown foods, some of those advantages being a better product quality, a favourable price/quality ratio and ensuring the origin of the purchased goods (Kawecka \& Gębarowski, 2015). Lombardi et al. (2015) claim that SFSC consumers have a more complex understanding of food quality, linking quality to sociological, ethical and ecological questions, as well as protecting the local production. According to Haas et al. (2013) the main consumer motive to purchase locally grown foods is the desire to promote health and to support the local community so that food is used to create a sense of identity and a feeling of belonging. When asked about the quality attributes of locally grown foods, consumers used terms such as healthier, fresher, tastier, natural products and the protection of the environment, while they often perceived it at the same time as expensive and inaccessible.

In their study of consumer behaviour and consumer opinions on food waste, Aktas et al. (2018) have come to the conclusion that consumer behaviour, which affects 
the creation of food waste in households, can be explained by using the Theory of Planned Behaviour (TPB). The central factor in the TPB is the intention of an individual to behave in a certain way. The intention includes motivational factors that will affect the behaviour of the individual, in other words these factors will show how much effort an individual is willing to put into a certain behaviour. The stronger the intention, the greater the probability that a certain behaviour will be performed (Ajzen, 1991).

There are a series of reasons why food waste occurs in the final consumption phase. For example, some of the reasons may be an excessive amount of food that has been bought, an excessive amount of food that has been used to prepare a meal, not long enough durability of food products, the incomprehensibility of the expressions 'use by' and 'best before', which are used to mark expiration dates. According to Koester (2018), if consumers bought food products every day, food loss and food waste could be reduced and transaction costs could be increased. Purchasing smaller amounts of food more frequently, which would reduce losses caused by excessive storage of food and which would simultaneously reduce transaction costs, allows the fresh agri-food products to get closer to the final consumer. This is particularly true for the consumer supply with fresh food products (fruit and vegetables and dairy products) that also generate the largest amounts of food waste in households.

\section{THE CONSUMER POTENTIAL AS A MODIFIER OF URBAN FOOD SUPPLY CHAINS}

Due to their consumer structure and potential, urban centres significantly determine the need to innovate various service processes. As one of the key processes in sustaining urban centres, food supply has to be based on efficient processing and information flow. The collecting and processing of information thus become key tools that create added value to products and service sector activities that require their internal and external business processes to be modelled in a holistic way. With the development of information communication technology, the term 'connectedness' has appeared, which encompasses two components: interaction and market access. Connected information systems of the stakeholders in the supply chain allow information sharing and mutual communication, while the market access of the stakeholders in the supply chain is at the same time no longer restricted in geographical terms. Supply chain management focusses on managing complex business processes carried out by numerous members in the supply chain, who act as one entity. Information systems play a key role in the information flow management because they receive, process and transfer information within the supply chain in an automated way. 


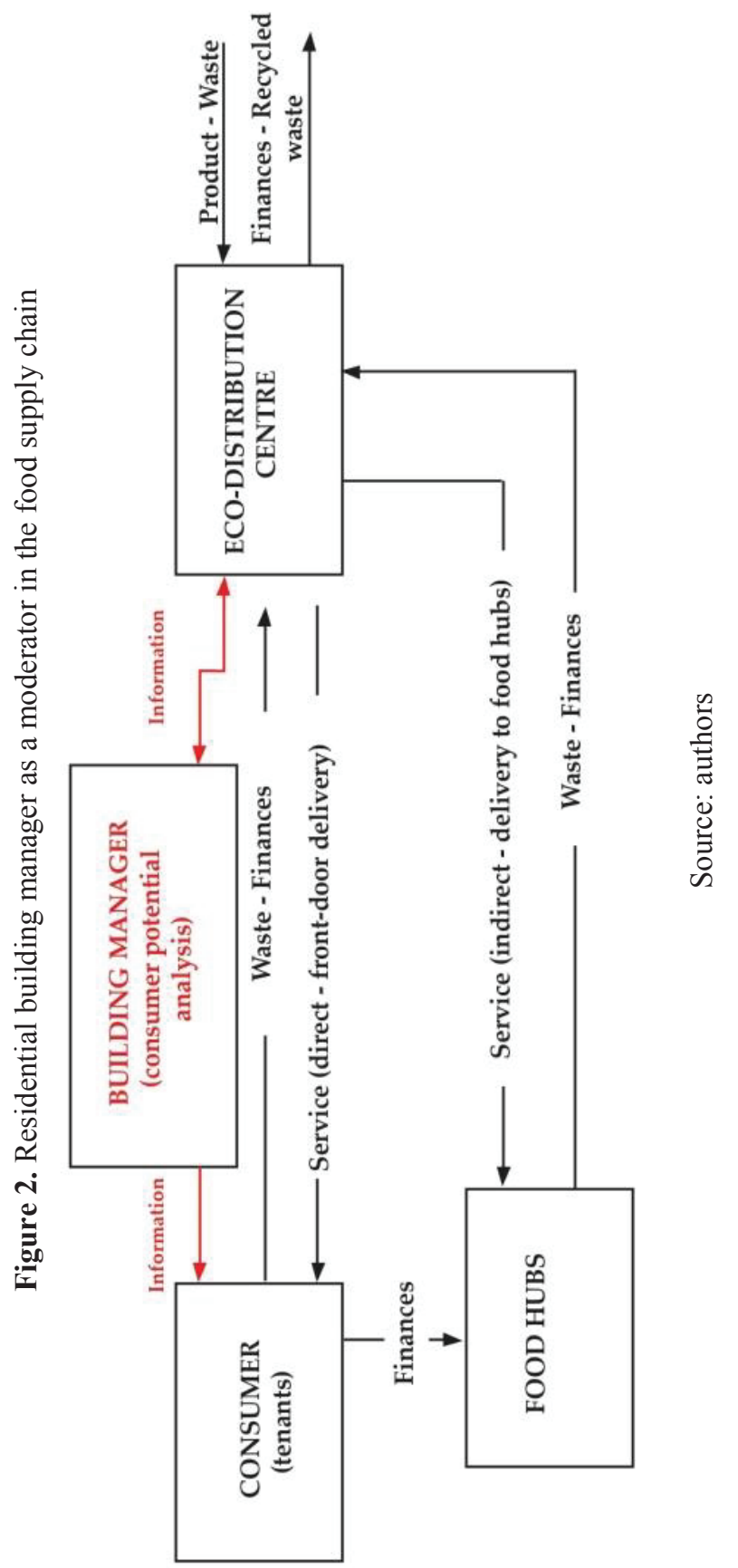


Food supply chains of urban centres are managed very efficiently by implementing innovative solutions, such as using e.g. residential building managers for the collection and processing of information (Figure 2).

Eco-distribution centres of agri-food products are designed according to consumer potential of urban centres, which has the following characteristics: (1) scope of demand for agri-food products (quantity of requested products), (2) structure of demand for agri-food products (types of requested products), (3) realisation of demand for agrifood products (directly to the front door or via food hubs). In order for supply chains to be able to respond to needs and desires of consumers, they need to be adaptive, thereby resulting in high-quality and continuous data processing by the service i.e. product provider. By using the services of a building manager as an agent in the bidirectional transfer of information (from consumers to producers and vice versa), the service provider is enabled a more efficient and more balanced utilisation of its own capacities. Food supply chain members achieve a double benefit owing to the existing and set-up data base of customers using services of a building manager: providing the consumer potential and efficient adapting to consumer needs. Depending on the feedback regarding dietary habits of consumers, participants in the short supply chain (producers and distributors) can plan and choose the following placement models for their products through an eco-distribution centre for agri-food products: (1) direct front-door delivery, (2) delivery to food hubs.

Both cases represent a model adapted to consumer needs, i.e. a smart product seeking its customer, rather than waiting for the customer to move uncontrollably toward the final product. When after-sales services of disposing and recycling of packaging and food waste is added to this model, the value of such a service is multiplied for its users. Moreover, a partner relationship and trust are developed between participants in the supply chain of agri-food products, which is extremely important when it comes to food products. A food supply chain modelled in such a way enables the customer to check the product traceability at all times, as well as information on the producer and the food production process. All this makes the model of eco-distribution centres a potential generator of added value for all members in the supply chain of agri-food products in urban centres and creates prerequisites for further continuous improvements of modern IT solutions.

\section{EMPIRICAL RESEARCH}

Empirically, we orient our research along the systematic literature review methodology. In our study, we first located relevant studies based on our review of studies which focus on why food waste occurs in the households. In the following sub- 
sections, we outline and discuss the research methodology. After that, we provide insights into individuals' perceptions and understandings of food waste. Furthermore, we present food-related practices and routines in the household that have been found to play a role in the generation of food waste. Finally, we explore the potential role of sociodemographic factors on food waste.

\subsection{Research methodology}

Consumer potential of urban centres was researched in collaboration with two utility companies of the city of Split. The research itself was conducted via highly structured questionnaire, which was developed, based on aforementioned literature review. Questionnaires were distributed to twenty residential buildings with 1110 households i.e. residential units and 148 tenants participated in the study. The empirical research was conducted during October and November 2019. The objectives of this research were to: (1) explore frequency of purchase of fresh agri-food products according to the place of purchase; (2) collect data on average weekly consumption of vegetables, fruits, meat, fish, milk and dairy products; (3) examine the respondents 'preferences about factors which influence their food purchase; (4) examine the respondents' perceptions of food waste and related issues in their households.

The response rate varied significantly per residential building, ranging from $0.00 \%$ to $32.65 \%$, thus indicating a lack of interest from the respondents for the issue of agri-food products supply and food waste disposal. Out of the twenty residential buildings processed, $20.00 \%$ accounts for smaller buildings (up to 30 residential units), whereas $40.00 \%$ accounts for medium-size (between 30 and 60 residential units) and other $40.00 \%$ for larger (more than 60 residential units) buildings.

The highest response, more than $20.00 \%$ was recorded in medium-sized residential buildings $(57.10 \%)$, whereas the response rate in smaller buildings amounted to $25.00 \%$. The worst response rate was recorded in high-rise buildings, amounting to as little as $12.50 \%$. This is due because high-rise buildings are the greatest consumption generators of agri-food products, thus also the greatest generators of food waste. Pursuant to the above, it is evident that activities encouraging sustainability of production and of food waste should be implemented. Individualisation of daily habits and an effort to achieve the greatest personal convenience possible does not contribute to the efficient management of food supply chains and to waste management in urban centres. It is, therefore, of the outmost priority to raise awareness of the existence of the mutual problem when it comes to food supply and waste management, and all social stakeholders should constantly address this priority. 


\subsection{Sociodemographic characteristics of the sample}

The following tables indicate sociodemographic characteristics of the sample. Table 1 depicts the household characteristic. Furthermore, Table 2 shows distribution of the household members in terms of age.

Table 1. Number of household members

\begin{tabular}{ll}
\hline NUMBER OF HOUSEHOLD MEMBERS & \multicolumn{1}{c}{ n (\%) } \\
\hline $\mathbf{1}$ or $\mathbf{2}$ household members & $76(51.40 \%)$ \\
$\mathbf{3}$ or $\mathbf{4}$ household members & $59(39.90 \%)$ \\
$\mathbf{5}$ and more household members & $13(8.80 \%)$ \\
\hline
\end{tabular}

Source: primary research

In terms of household members in the researched area, $51.40 \%$ of respondents live in household with 1 or 2 members, followed by $39.90 \%$ of respondents living in households with 3 or 4 household members, while only $8.80 \%$ of the sample lives in household with 5 and more members.

Table 2. Distribution of household members in terms of age

\begin{tabular}{|c|c|c|c|}
\hline $\begin{array}{l}\text { NUMBER OF } \\
\text { HOUSEHOLD } \\
\text { MEMBERS }\end{array}$ & $\begin{array}{l}\text { HOUSEHOLOD } \\
\text { MEMBERS } \\
\text { UNDER } 18 \\
\text { YEARS OF AGE }\end{array}$ & $\begin{array}{l}\text { HOUSEHOLOD } \\
\text { MEMBERS } \\
\text { BETWEEN } 18 \\
\text { AND } 65 \text { YEARS } \\
\text { OF AGE }\end{array}$ & $\begin{array}{l}\text { HOUSEHOLD } \\
\text { MEMBERS } \\
\text { OLDER THAN } \\
65 \text { YEARS }\end{array}$ \\
\hline $\mathbf{0}$ & $104(70.30 \%)$ & $38(25.70 \%)$ & $75(50.70 \%)$ \\
\hline 1 member & $22(14.90 \%)$ & $44(29.70 \%)$ & $40(27.00 \%)$ \\
\hline 2 members & $19(12.80 \%)$ & $38(25.70 \%)$ & $30(20.30 \%)$ \\
\hline $\begin{array}{l}3 \text { and more } \\
\text { members }\end{array}$ & $3(2.00 \%)$ & $28(18.90 \%)$ & $3(2.00 \%)$ \\
\hline
\end{tabular}

Source: primary research

\subsection{Respondent's food habits}

Furthermore, respondents were asked about their frequency of purchase of fresh agri-food products according to the place of purchase, such as neighbourhood store, retail centres, local markets, home delivery and via Internet. As expected, and can be seen from 
the Table 3, most of the respondents frequently buy food from neighbourhood stores, followed by retail centres and local markets.

Table 3. Frequency of purchase of fresh agri-food products according to the place of purchase

\begin{tabular}{lccccc}
\hline & $\begin{array}{c}\text { NEIGHBOURHOO } \\
\text { D STORES }\end{array}$ & $\begin{array}{c}\text { RETAIL } \\
\text { CENTRE } \\
\text { S }\end{array}$ & $\begin{array}{c}\text { LOCAL } \\
\text { MARKET }\end{array}$ & $\begin{array}{c}\text { HOME } \\
\text { DELIVER }\end{array}$ & $\begin{array}{c}\text { VIA } \\
\text { INTERNE } \\
\text { T }\end{array}$ \\
\hline $\begin{array}{l}\text { I do not } \\
\text { buy }\end{array}$ & 52 & 59 & $51(39.90 \%)$ & 138 & 143 \\
I rarely & $(35.10 \%)$ & $(39.90 \%)$ & & $(93.20 \%)$ & $(96.60 \%)$ \\
buy & 23 & 29 & $24(19.60 \%)$ & 6 & 3 \\
$\begin{array}{l}\text { I often } \\
\text { buy }\end{array}$ & $(15.50 \%)$ & $(19.60 \%)$ & & $(4.10 \%)$ & $(2.00 \%)$ \\
most & 25 & 36 & $22(24.30 \%)$ & 2 & 1 \\
often I & $(16.90 \%)$ & $(24.30 \%)$ & & $(1.40 \%)$ & $(0.70 \%)$ \\
buy & 48 & 24 & 51 & 2 & 1 \\
TOTA & $(32.40 \%)$ & $(16.20 \%)$ & $(16.20 \%)$ & $(1.40 \%)$ & $(0.70 \%)$ \\
L & 148 & & & & 148 \\
\hline
\end{tabular}

Source: primary research

According to the research (Gajdic et al., 2019) conducted with the aim of obtaining information on the perception and attitudes with regard to food safety in the Republic of Croatia, 64 out of 165 respondents stated that most often they buy food only in supermarkets $(38.80 \%)$, to a lesser extent both at farmers markets and in supermarkets $(16.40 \%)$, and the least both in supermarkets and in small specialised stores $(12.70 \%)$. Another research conducted in Latvia (Krivašonoka et al., 2015), the majority of Latvian respondents also buy agri-food products in supermarkets $(70.00 \%), 16 \%$ of them buy such products in specialised stores, $7.00 \%$ of respondents shop at farmers markets, and $1 \%$ buy agri-food products directly from farmers. Research conducted in the Czech Republic (Stávková et al., 2006), 65.08\% of respondents buy agri-food products in supermarkets, $33.52 \%$ in retail stores, as little as $1.12 \%$ of respondents buy agri-food products in specialised stores and $0.28 \%$ of them shop at farmers markets and directly from farmers.

When asked about their frequency of purchasing fresh food products, respondents replied as follows: every day $(20.90 \%)$, four to five times a week $(17.60 \%)$, two to three times a week $(41.90 \%)$, once a week (18.90\%). 
Table 4. Average monthly consumption of food in the household

\begin{tabular}{rlllll}
\hline & $\begin{array}{l}\text { average } \\
\text { monthly } \\
\text { consumption } \\
\text { of vegetables } \\
\text { in the } \\
\text { household }\end{array}$ & $\begin{array}{l}\text { average } \\
\text { monthly } \\
\text { consumption } \\
\text { of fruits in } \\
\text { the household }\end{array}$ & $\begin{array}{l}\text { average } \\
\text { monthly } \\
\text { consumption } \\
\text { of meat in the } \\
\text { household }\end{array}$ & $\begin{array}{l}\text { average } \\
\text { monthly } \\
\text { consumption } \\
\text { of fish in the } \\
\text { household }\end{array}$ & $\begin{array}{l}\text { average } \\
\text { monthly } \\
\text { consumption } \\
\text { of milk and } \\
\text { dairy in the } \\
\text { household }\end{array}$ \\
\hline $\mathbf{0}$ & 1 & 3 & 10 & 25 & 6 \\
& $(0.70 \%)$ & $(2.00 \%)$ & $(6.80 \%)$ & $(16.90 \%)$ & $(4.10 \%)$ \\
\hline up to $\mathbf{1}$ & 35 & 35 & 54 & 85 & 43 \\
$\mathbf{~ k g}$ & $(23.60 \%)$ & $(23.60 \%)$ & $(36.50 \%)$ & $(57.40 \%)$ & $(29.10 \%)$ \\
from $\mathbf{1}$ & 55 & 52 & 49 & 29 & 44 \\
to $\mathbf{2} \mathbf{~ k g}$ & $(37.2 \%)$ & $(35.10 \%)$ & $(33.10 \%)$ & $(19.60 \%)$ & $(29.70 \%)$ \\
$\mathbf{2}$ and & 57 & 58 & 35 & 9 & 55 \\
$\mathbf{m o r e}$ & $(38.50 \%)$ & $(39.20 \%)$ & $(23.60 \%)$ & $(6.10 \%)$ & $(37.20 \%)$ \\
$\mathbf{~ k g}$ & & & & & \\
\hline
\end{tabular}

Source: primary research

Average monthly consumption of vegetables in the households is 2 and more $\mathrm{kg}$ (38.50\%), average monthly consumption of fruits in the households is 2 and more $\mathrm{kg}$ (39.20\%), average monthly consumption of meat in the household is up to $1 \mathrm{~kg}(36.50 \%)$, average monthly consumption of fish in the household is up to $1 \mathrm{~kg}$ and average monthly consumption of mild and dairy in the household is 2 and more $\mathrm{kg}$ (Table 4).

Respondents' rating of individual characteristics in the selection of food products was examined by using the Likert scale, which measures respondents' agreement with certain statements, where 1 represented complete disagreement and 5 complete agreements with the statement.

The aim of the research conducted by Litavniece et al. (2017) was to establish how often modern consumers buy local food and their attitude towards it. More than 500 Latvian respondents were questioned and, according to survey results, when buying food consumers pay the most attention to food quality, expiration date and price. The respondents purportedly regularly buy food from local food producers. The consumers' behaviour is influenced by the country's economic development and the level of education. The authors concluded on the basis of this research that the demand for highquality food - in this case also for local food - rises with the rise of the level of education. In the research conducted by Cembalo et al. (2015) the respondents highlighted the following benefits of buying agri-food products from producers: freshness, flavour, health, price, quality, safety and product information. In our research, freshness of the 
product was rated as the most important individual characteristics in the selection of food product (Table 5).

Table 5. Rating of individual characteristics important in the selection of food products

\begin{tabular}{|c|c|c|c|c|c|}
\hline & MEAN & MEDIAN & MODE & $\begin{array}{l}\text { STANDARD } \\
\text { DEVIATION }\end{array}$ & VARIANCE \\
\hline $\begin{array}{l}\text { freshness of the } \\
\text { products }\end{array}$ & 4.48 & 5.00 & 5 & 1.097 & 1.204 \\
\hline $\begin{array}{l}\text { organoleptic } \\
\text { properties (taste and } \\
\text { / or smell) }\end{array}$ & 4.16 & 4.00 & 5 & 1.044 & 1.089 \\
\hline $\begin{array}{l}\text { product is from } \\
\text { organic production }\end{array}$ & 3.84 & 4.00 & 5 & 1.088 & 1.184 \\
\hline $\begin{array}{l}\text { availability } \\
\text { (proximity to the } \\
\text { point of sale) }\end{array}$ & 3.91 & 4.00 & 5 & 1.178 & 1.387 \\
\hline $\begin{array}{l}\text { product was } \\
\text { produced by familiar } \\
\text { producer }\end{array}$ & 3.40 & 4.00 & $4^{a}$ & 1.202 & 1.444 \\
\hline $\begin{array}{l}\text { possibility of delivery } \\
\text { to the doorstep }\end{array}$ & 2.32 & 2.00 & 1 & 1.350 & 1.824 \\
\hline product variety & 3.96 & 4.00 & 5 & 1.130 & 1.277 \\
\hline product packaging & 3.33 & 3.00 & 4 & 1.242 & 1.543 \\
\hline product price & 3.79 & 4.00 & 5 & 1.279 & 1.636 \\
\hline
\end{tabular}

a. Multiple modes exist. The smallest value is shown

Source: primary research

To determine factors which influence the selection of food products in more detail, factor analysis was performed using the principal component method with the Kaiser-Guttman criterion and varimax rotation. Data analysis extracted two factors with a characteristic root greater than one that together explain $54.509 \%$ of the variance. The shown factor matrix in Table 6 was obtained after varimax rotation. 
Table 6. Factor matrix of the factors which influence the selection of food products

\begin{tabular}{lcc}
\hline \multicolumn{1}{c}{ FACTORS } & \multicolumn{2}{c}{ FACTOR LOADINGS } \\
\hline \multicolumn{1}{|c}{ PRODUCT CHARACTERISTICS } & 1 & 2 \\
\hline product price & $\mathbf{. 8 0 2}$ & \\
organoleptic properties (taste and / or smell) & $\mathbf{. 6 4 6}$ & \\
freshness of the products & $\mathbf{. 6 4 2}$ & \\
product variety & $\mathbf{. 6 3 4}$ & .457 \\
availability (proximity to the point of sale) & $\mathbf{. 6 2 0}$ & \\
\hline \multicolumn{1}{|c|}{ PRODUCTION CHARACTERISTICS } & .502 & $\mathbf{. 3 6 5}$ \\
\hline product packaging & & $\mathbf{. 8 5 6}$ \\
product is from organic production & & $\mathbf{. 7 6 1}$ \\
\hline product was produced by familiar producer & & \\
\hline
\end{tabular}

Source: primary research

Factor product characteristics comprises of 5 items related to the price of the product, organoleptic properties (taste and / or smell), freshness of the product, product variety, availability (proximity to the point of sale). The second extracted factor is called the production characteristics and contains 3 items that describe product packaging, that the product is from organic production and that it was produced by a familiar producer. Descriptive indicators are presented in the Table 7.

Table 7. Descriptive indicators of the factors which influence food products selection

\begin{tabular}{ccc}
\hline & 148 & 148 \\
& 4.06 & 3.60 \\
\hline $\mathbf{n}$ & .819 & .883 \\
$\mathbf{\alpha}$ & 1 & 1 \\
$\mathbf{M}$ & 5 & 5 \\
$\mathbf{M}$ Max & -1.861 & -.900 \\
\hline Skewness & .199 & .199 \\
Std. Error of Skewness & 4.242 & 1.260 \\
Kurtosis & .396 & .396 \\
\hline Std. Error of Kurtosis & .710 & .759 \\
\hline $\boldsymbol{\alpha}$ &
\end{tabular}

Source: primary research 
The normality of the distribution of variables was tested by the KolmogorovSmirnov test, which showed that the distribution was significantly different from the normal one, therefore, nonparametric tests were used. To determine whether there was a statistically significant difference in attitudes toward product characteristics and production characteristics, with respect to the number of household members, a KruskalWallis test was conducted. Table 8 shows the mean of rankings of respondents' attitudes toward product characteristics and production characteristics with respect to the number of household members.

Table 8. Mean rank of attitudes toward product characteristics and production characteristics given the number of household members

\begin{tabular}{cccc}
\hline & $\begin{array}{c}\text { NUMBER OF } \\
\text { HOUSEHOLOD } \\
\text { MEMBERS }\end{array}$ & n & M RANKS \\
\hline ATTITUDES & 1 and 2 & 76 & 76.03 \\
TOWARDS & 3 and 4 & 59 & 76.34 \\
PRODUCT & 5 and more & 13 & 57.23 \\
CHARACTERISTICS & TOTAL & 148 & \\
ATTITUDES & 1 and 2 & 76 & 73.36 \\
TOWARDS & 3 and 4 & 59 & 80.86 \\
PRODUCTION & 5 and more & 13 & 52.31 \\
CHARACTERISTICS & TOTAL & 148 & \\
\hline
\end{tabular}

Source: primary research

The results indicate that there is no statistically significant difference in attitudes toward product characteristics with respect to the number of household members $\left(\chi^{2}=\right.$ $.310, \mathrm{df}=2, \mathrm{p}>0.05)$, as well as no statistically significant difference in attitudes toward food production characteristics with respect to the number of household members $\left(\chi^{2}=\right.$ $.085, \mathrm{df}=2, \mathrm{p}>0.05)$.

To determine whether there was a statistically significant difference in attitudes toward product characteristics and food production characteristics, with respect to the number of household members under 18 years of age, the Kruskal-Wallis test was again conducted. There was no statistically significant difference in attitudes towards product characteristics with respect to the number of household members under 18 years of age $\left(\chi^{2}=4.824, \mathrm{df}=3, \mathrm{p}>0.05\right)$, as well as no statistically significant difference in attitudes toward production characteristics with respect to the number of household members 
under 18 years of age $\left(\chi^{2}=3.595, \mathrm{df}=3, \mathrm{p}>0.05\right)$. To determine the statistically significant difference in attitudes toward product and production characteristics, with respect to the number of household members from 18 to 65 years of age, a Kruskal-Wallis test was performed. The Kruskal-Wallis test found that there was no statistically significant difference in attitudes towards product characteristics with respect to the number of household members aged 18 to $65\left(\chi^{2}=.857, \mathrm{df}=3, \mathrm{p}>0.05\right)$, as well as no statistically significant difference in attitudes towards production characteristics with respect to the number of household members aged 18 to $65\left(\chi^{2}=1.945, \mathrm{df}=3, \mathrm{p}>0.05\right)$. To determine whether there is a statistically significant difference in those attitudes with respect to the number of household members over 65 years of age, again a Kruskal-Wallis test was performed. The results indicate that there is no statistically significant difference in attitudes towards product characteristics with respect to the number of household members older than $65\left(\chi^{2}=2.098, \mathrm{df}=2, \mathrm{p}>0.05\right)$, as well as no statistically significant difference in attitudes toward production characteristics with respect to the number of household members $65+\left(\chi^{2}=3.635, \mathrm{df}=2, \mathrm{p}>0.05\right)$.

\subsection{Respondents perceptions of food waste and related issues in their households}

Respondents' rating of food waste and related issues in their households was examined by using the Likert scale, which measures respondents' agreement with certain statements, where 1 represented complete disagreement and 5 complete agreements with the statement. Table 9. shows rating of individual characteristics connected with food waste generation. The research about reasons for food waste generation in households were also previously researched in the Republic of Croatia in 2017 by Ilakovac et al. (2018) with the aim of determining how the behaviour of household population affects the generation of food waste. According to the results, the most common reason for food waste generation in Croatian households is cooking excessive amounts of food. 
Table 9. Rating of individual characteristics connected with food waste generation

\begin{tabular}{|c|c|c|c|c|c|}
\hline & MEAN & MEDIAN & MODE & $\begin{array}{l}\text { STANDARD } \\
\text { DEVIATION }\end{array}$ & VARIANCE \\
\hline $\begin{array}{l}\text { Improving logistical } \\
\text { solutions for food waste } \\
\text { management could } \\
\text { achieve environmental } \\
\text { benefits. }\end{array}$ & 4.29 & 5.00 & 5 & 1.102 & 1.214 \\
\hline $\begin{array}{l}\text { Recycling or processing } \\
\text { of unused food is an } \\
\text { alternative way of } \\
\text { reducing waste. }\end{array}$ & 4.10 & 4.00 & 5 & 1.055 & 1.112 \\
\hline $\begin{array}{l}\text { Organized collection of } \\
\text { unused food products } \\
\text { would reduce waste. }\end{array}$ & 4.28 & 5.00 & 5 & 1.029 & 1.059 \\
\hline $\begin{array}{l}\text { With more frequent } \\
\text { purchases of smaller } \\
\text { quantities of food, I } \\
\text { reduce the excessive } \\
\text { storage of food which is } \\
\text { leading to food loss (e.g. } \\
\text { due to expiry or } \\
\text { spoilage. }\end{array}$ & 2.80 & 3.00 & 1 & 1.475 & 2.176 \\
\hline $\begin{array}{l}\text { Food waste is higher in } \\
\text { urban households. }\end{array}$ & 3.83 & 4.00 & 5 & 1.264 & 1.597 \\
\hline $\begin{array}{l}\text { Too much food is } \\
\text { thrown away in my } \\
\text { household. }\end{array}$ & 1.89 & 2.00 & 1 & 1.138 & 1.294 \\
\hline $\begin{array}{l}\text { With less frequent } \\
\text { purchases of larger } \\
\text { quantities of food, more } \\
\text { household waste is } \\
\text { generated in my } \\
\text { household. }\end{array}$ & 4.03 & 4.00 & 5 & 1.145 & 1.312 \\
\hline $\begin{array}{l}\text { Food waste also occurs } \\
\text { due to inadequate } \\
\text { packaging. }\end{array}$ & 3.39 & 4.00 & 4 & 1.291 & 1.667 \\
\hline $\begin{array}{l}\text { Food waste disposal is } \\
\text { well organized in the } \\
\text { area where I live. }\end{array}$ & 1.93 & 2.00 & 1 & 1.119 & 1.253 \\
\hline $\begin{array}{l}\text { I consider food that has } \\
\text { expired food waste. }\end{array}$ & 3.35 & 4.00 & 5 & 1.452 & 2.107 \\
\hline
\end{tabular}

Source: primary research

Factor analysis was also performed using the principal components method using the Kaiser-Guttman criterion and varimax rotation to determine factors associated with 
food waste issue. Two factors with a characteristic root greater than one were extracted, which together explain $50.651 \%$ of the variance. Table 10 shows the factor matrix obtained after varimax rotation.

Table 10. Factor matrix of the factors associated with food waste issues

\begin{tabular}{|c|c|c|}
\hline FACTORS & \multicolumn{2}{|c|}{ FACTOR LOADINGS } \\
\hline $\begin{array}{l}\text { REDUCING FOOD WASTE } \\
\end{array}$ & 1 & 2 \\
\hline $\begin{array}{l}\text { Improving logistical solutions for food waste management } \\
\text { could achieve environmental benefits. }\end{array}$ & .878 & \\
\hline $\begin{array}{l}\text { Recycling or processing of unused food is an alternative way } \\
\text { of reducing waste. }\end{array}$ & .875 & \\
\hline $\begin{array}{l}\text { Organized collection of unused food products would reduce } \\
\text { waste. }\end{array}$ & .823 & \\
\hline $\begin{array}{l}\text { With more frequent purchases of smaller quantities of food, I } \\
\text { reduce the excessive storage of food which is leading to food } \\
\text { loss (e.g. due to expiry or spoilage. }\end{array}$ & .638 & \\
\hline Food waste is higher in urban households. & .485 & \\
\hline \multicolumn{3}{|l|}{ HOUSEHOLD FOOD WASTE } \\
\hline Too much food is thrown away in my household. & & .733 \\
\hline $\begin{array}{l}\text { With less frequent purchases of larger quantities of food, } \\
\text { more household waste is generated in my household. }\end{array}$ & & .709 \\
\hline Food waste also occurs due to inadequate packaging. & & 609 \\
\hline Food waste disposal is well organized in the area where I live. & & .580 \\
\hline I consider food that has expired food waste. & & .464 \\
\hline
\end{tabular}

Source: primary research

The first factor, called reducing food waste, includes five items: (1) Improving logistical solutions for food waste management could achieve environmental benefits., (2) Recycling or processing of unused food is an alternative way of reducing waste., (3) Organized collection of unused food products would reduce waste., (4) With more frequent purchases of smaller quantities of food, I reduce the excessive storage of food which is leading to food loss (e.g. due to expiry or spoilage)., (5) Food waste is higher in urban households. The second factor is called household food waste and it includes five statements: (1) Too much food is thrown away in my household., (2) With less frequent purchases of larger quantities of food, more household waste is generated in my household., (3) Food waste also occurs due to inadequate packaging., (4) Food waste disposal is well organized in the area where I live., (5) I consider food that has expired food waste. Descriptive indicators of the factors associated with food waste issues are presented in the Table 11. 
Table 11. Descriptive indicators of the factors associated with food waste issues

\begin{tabular}{|c|c|c|}
\hline & 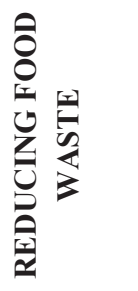 & 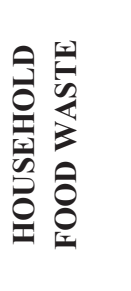 \\
\hline $\mathbf{n}$ & 148 & 148 \\
\hline $\mathbf{M}$ & 4.10 & 2.67 \\
\hline$\sigma$ & .837 & .826 \\
\hline Min & 1 & 1 \\
\hline Max & 5 & 5 \\
\hline Skewness & -1.542 & -1.542 \\
\hline $\begin{array}{l}\text { Std. Error of } \\
\text { Skewness }\end{array}$ & .199 & .199 \\
\hline Kurtosis & 3.058 & .100 \\
\hline $\begin{array}{l}\text { Std. Error of } \\
\text { Kurtosis }\end{array}$ & .396 & .396 \\
\hline$\alpha$ & .802 & .728 \\
\hline
\end{tabular}

Source: primary research

The Kruskal-Wallis test was conducted to determine whether there was a statistically significant difference in attitudes toward factor reducing food waste and factor household food waste with respect to the number of household members. Table 12 shows the mean of the rankings of respondents' attitudes toward reducing food waste and household food waste with respect to the number of household members. 
Table 12. Mean rank of attitudes toward reducing food waste and household food waste given the number of household members

\begin{tabular}{cccc}
\hline & $\begin{array}{c}\text { NUMBER OF } \\
\text { HOUSEHOLOD } \\
\text { MEMBERS }\end{array}$ & $\mathbf{n}$ & M RANKS \\
\hline ATTITUDES & 1 and 2 & 76 & 75.24 \\
TOWARDS & 3 and 4 & 59 & 74.92 \\
REDUCING FOOD & 5 and more & 13 & 68.27 \\
WASTE & TOTAL & 148 & \\
ATTITUDES & 1 and 2 & 76 & 70.10 \\
TOWARDS & 3 and 4 & 59 & 80.71 \\
HOUSEHOLD FOOD & 5 and more & 13 & 72.04 \\
WASTE & TOTAL & 148 & \\
\hline
\end{tabular}

Source: primary research

The Kruskal-Wallis test found statistically significant difference in attitudes toward reducing food waste with respect to the number of household members $\left(\chi^{2}=.308\right.$, $\mathrm{df}=2, \mathrm{p}<0.05)$. At the same time, there was statistically significant difference in attitudes towards household food waste with respect to the number of household members $\left(\chi^{2}=\right.$ 2.097 , $\mathrm{df}=2, \mathrm{p}<0.05)$. To determine whether there was a statistically significant difference in attitudes toward factors with respect to the number of household members under 18, the Kruskal-Wallis test was again conducted. There was no statistically significant difference in attitudes towards reducing food waste with respect to the number of household members $\left(\chi^{2}=4.198, \mathrm{df}=3, \mathrm{p}>0.05\right)$, as well as no statistically significant difference in attitudes toward household food waste with respect to the number of household members $\left(\chi^{2}=.885, \mathrm{df}=3, \mathrm{p}>0.05\right)$. The Kruskal-Wallis test found that there was statistically significant difference in attitudes towards reducing food waste with respect to the number of household members aged 18 to $65\left(\chi^{2}=.857, \mathrm{df}=3, \mathrm{p}<0.05\right)$, who care more about food waste, as well as statistically significant difference in attitudes towards household food waste with respect to the number of household members aged 18 to $65\left(\chi^{2}=1.945, \mathrm{df}=3, \mathrm{p}<0.05\right)$. The Kruskal-Wallis test found that there was no statistically significant difference in attitudes towards reducing food waste with respect to the number of household members aged over $65\left(\chi^{2}=.857, \mathrm{df}=3, \mathrm{p}>0.05\right)$, as well as no statistically significant difference in attitudes towards household food waste with respect to the number of household members aged over $65\left(\chi^{2}=1.945, \mathrm{df}=3, \mathrm{p}>0.05\right)$. 


\section{CONCLUSION}

The aim of this research was to explain the potential of the urban centres for the food supply chain management and strategic development of cities. As such, we propose a simple possible solution for the continuous and sustainable supply for the urban population is the development of eco-distribution centres for agri-food products. With the implementation of the eco-distribution center, numerous positive effects can be achieved, one of which is more efficient food supply for local population which can control the production and disposal of food waste. Empirical research results indicate lack of understanding of food supply chain management processes, especially the one connected with food waste reduction. Tenants do not seem to prioritise the aforementioned food disposal problems yet, although expected benefits are obvious. Further empirical research is needed so as to clarify whether agricultural producers share the positive attitude towards this idea of eco-distribution centres or not. Such research is beneficial as it would focus on the analysis of capacities and motivation of agricultural producers to participate in this form of short supply chain.

\section{REFERENCES:}

1. Ajzen, I. (1991). The Theory of Planned Behavior. Organizational Behavior and Human Decision Processes, 50 (2), 179-211. https://doi.org/10.1016/07495978(91)90020-T

2. Aktas, E., Sahin, H., Topaloglu, Z., Oledinma, A., Huda, A.K.S., Irani, Z., Sharif, A.M., van't Wout, T., Kamrava, M. (2018). A consumer behavioural approach to food waste. Journal of Enterprise Information Management, 31(5), 658-673. https://doi.org/10.1108/JEIM-03-2018-0051

3. Albanesi, C., Cicognani, E., Zani, B. (2007). Sense of community, civic engagement and social well-being in Italian adolescents. Journal of Community \& Applied Social Psychology, 17(5), 387-406. https://doi.org/10.1002/casp.903

4. Arsil, P., Li, E., Bruwer, J., Lyons, G. (2014). Exploring consumer motivations toward buying local fresh food products: A means-end chain approach. British Food Journal, 116(10), 1533-1549. https://doi.org/10.1108/BFJ-04-2013-0083

5. Berti, G., Mulligan, C. (2016). Competitiveness of small farms and innovative food supply chains: The role of food hubs in creating sustainable regional and local food systems. Sustainability, 8(7), 616, doi:10.3390/ su8070616

6. Blondin, S., Djang, H., Metayer, N., Anzman-Frasca, S., Economos, C. (2014). It's just so much waste, A qualitative investigation of food waste in a universal 
free school breakfast program. Public Health Nutrition, 18(9), 1565-1577. doi:10.1017/S1368980014002948

7. Bloom, J. (2011). American Wasteland: How America Throws Away Nearly Half of It's Food (and What We Can Do About It), Publisher, Da Capo Lifelong Books, Boston

8. Brehm, J. M., Eisenhauer, B. W., Krannich, R. S. (2006). Community Attachments as Predictors of Local Environmental Concern: The Case for Multiple Dimensions of Attachment. American Behavioral Scientist, 50(2) 142165. https://doi.org/10.1177\%2F0002764206290630

9. Buzby, Jean C., Hodan, W., Jeffrey H. (2014). The Estimated Amount, Value, and Calories of Postharvest Food Losses at the Retail and Consumer Levels in the United States, Department of Agriculture, Economic Research Service, SSRN Electronic Journal, DOI: 10.2139/ssrn.2501659

10. Cembalo, L., Lombardi, A., Pascucci, S., Dentoni, D., Migliore, G., Verneau, F., Schifani, G., (2015). "Rationally Local": Consumer Participation in Alternative Food Chains. Agribusiness: An International Journal, 31(3), 330352. https://doi.org/10.1002/agr.21419

11. Costello, C., Birisci, E., McGarvey R. (2015). Food waste in campus dining operations: Inventory of pre-and post-consumer mass by food category, and estimation of embodied greenhouse gas emissions. Renewable Agriculture and Food Systems, 31(3), 191-201. https://doi.org/10.1017/S1742170515000071

12. Davoudi, S., Stead, D. (2002). Urban-Rural Relationships: an introduction and a brief history. Built Environment: 28(4), 269-277. DOI: 10.2307/23287748

13. FAO (2011). Global food losses and food waste - Extent, causes and prevention, Rome, Available at: http://www.fao.org/3/mb060e/mb060e00.htm

14. Gajdić, D. (2019). Definiranje i obilježja kratkih opskrbnih lanaca poljoprivredno prehrambenih proizvoda (Definition and characteristics of short agri-food supply chains for products). Ekonomska misao i praksa (Economic Thought and Practice), 28(1), 381-407. http://hrcak.srce.hr/emp?lang=en

15. Gajdić, D., Petljak, K., Kralj, N. (2019). Percepcije potrošača o sigurnosti hrane u sjeverozapadnoj Hrvatskoj. $54^{\text {th }}$ Croatian $\& 14^{\text {th }}$ International Symposium on Agriculture, Proceedings, 107-112., Available at: https://bib.irb.hr/datoteka/1006866.Proceedings_2019.pdf

16. Giampietri, E., Finco, A., Del Giudice, T. (2016). Exploring consumers' behaviour towards short food supply chains. British Food Journal, 118(3), 618631. https://doi.org/10.1108/BFJ-04-2015-0168 
17. Govindan, K. (2018). Sustainable Consumption and Production in the Food Supply Chain: A Conceptual Framework. International Journal of Production Economics, 195, 419-431. https://doi.org/10.1016/j.ijpe.2017.03.003

18. Gustavsson, J., Cederberg, C., Sonesson, U. (2011). Global food losses and food waste-extent, causes and prevention. Study, Dusseldorf: Food and Agriculture organization of the United Nations, 2-3.

19. HAOP (2018). Unaprjeđenje sustava za prikupljanje podataka o biootpadu i otpadu hrane, izlazni rezultat, (Improvement of the system for collecting data on bio-waste and food waste, output result) Available at: http://www.haop.hr/sites/default/files/uploads/dokumenti/021_otpad/Projekti/S C18313\%20Biootpad\%20i\%20otpad\%20od\%20hrane\%20\%20rezultat\%201\% 20FINAL $\% 20 Z$ Z $\% 20$ WEB $\% 20$ (bez $\% 20$ podataka $\% 20 \mathrm{MP} \% 20 \mathrm{i} \% 20$ PRILOGA L_rev.pdf

20. Haas, R., Sterns, J., Meixner, O., Nyob, D. I., Traar, V. (2013). Do US consumers' perceive local and organic food differently? An analysis based on means-end chain analysis and word association. International Journal of Food System Dynamics, 4(3), 214-226. https://doi.org/10.18461/ijfsd.v4i3.435

21. Ilakovac, B., Iličković, M., Voća, N. (2018). Food waste in Croatian households. Journal of Central European Agriculture, 19(3), 678-709. https://doi.org/10.5513/JCEA01/19.3.1994

22. Kawecka, A., Gębarowski, M. (2015). Short food supply chains - benefits for consumers and food producers. Journal of Agribusiness and Rural Development, 3(37), 459-466. DOI: 10.17306/JARD.2015.48

23. Kesić, T. (2006). Ponašanje potrošača, 2. izmijenjeno $i$ dopunjeno izdanje, Opinio d.o.o., Zagreb

24. Knežević, B., Marić, I., Šućur Z. (2017). Međusektorska suradnja u području distribucije hrane kao odgovor na probleme siromaštva i materijalne deprivacije. Revija za socijalnu politiku, 24 (2), 143-167. doi: 10.3935/rsp.v24i2.1410

25. Koester, U. (2017). Food Loss and Waste as an Economic and Policy Problem. World Agricultural Resources and Food Security (Frontiers of Economics and Globalization), 17, 275-288. https://doi.org/10.1108/S1574$\underline{871520170000017018}$

26. Kovačić, D. (2005). Izravna prodaja seljačkih proizvoda-teorijska polazišta $i$ praktična primjena, Agrarno Savjetovanje, Zagreb

27. Krešić G. (2012). Trendovi u prehrani, Sveučilišna knjižnica Rijeka

28. Krivašonoka, I., Siliņa, L. (2015). Theoretical aspects of local food distribution. Economics, Research for Rural Development, 2, 276-283. 
29. Liljestrand, K. (2017). Logistics solutions for reducing food waste. International Journal of Physical Distribution \& Logistics Management, 47(4), 318-339. https://doi.org/10.1108/IJPDLM-03-2016-0085

30. Lipinski, B., Hanson, C., Lomax, J., Kitinoja, L., Waite, R., Searchinger, T. (2013). Reducing food loss and waste. Working paper of World Resources Institute, Washington, DC. Available at: https://www.wri.org/publication/reducing-food-loss-and-waste

31. Litavniece, L., Silicka, I., Dembovska, I., Tretjakova, R. (2017). The significance of local food in the consumption of modern consumer. Conference paper: $11^{\text {th }}$ Baltic Conference on Food Science and Technology "Food science and technology in a changing world" FOODBALT 2017, 189-194. DOI:10.22616/foodbalt.2017.033

32. Lombardi, A., Migliore, G., Verneau, F., Schifani, G., Cembalo, L. (2015). Are "good guys" more likely to participate in local agriculture? Food Quality and Preference, 45, 158-165. https://doi.org/10.1016/j.foodqual.2015.06.005

33. Migliore, G., Schifani, G., Romeo, P., Hashem, S., Cembalo, L. (2015). Are Farmers in Alternative Food Networks Social Entrepreneurs? Evidence from a Behavioral Approach. Journal of Agricultural and Environmental Ethics, 28(5), 885-902. DOI 10.1007/s10806-015-9562-y

34. Parfitt, J., Barthel, M., Macnaughton, S. (2010). Food waste within food supply chains: Quantification and potential for change to 2050. Philosophical Transactions of The Royal Society, 365(1554), 3065-3081. https://doi.org/10.1098/rstb.2010.0126

35. Perkins, D. D., Hughey, J., Speer, P. W. (2002). Community psychology perspectives on social capital theory and community development practice. Journal of the Community Development Society, 33(1), 33-52. https://doi.org/10.1080/15575330209490141

36. Perkins, D. D., Long, D. A. (2002). Neighborhood sense of community and social capital: A multi-level analysis. In A. Fisher, C. Sonn, \& B. Bishop (Eds.), Psychological sense of community: Research, applications, and implications, 291-318. New York: Plenum

37. Program za provedbu Plana sprječavanja i smanjenja nastajanja otpada od hrane Republike Hrvatske 2019.-2022. (Program for implementation of the Plan for the prevention and reduction of food waste from the Republic of Croatia 2019.2020.)

Available

at:

https://poljoprivreda.gov.hr/UserDocsImages/dokumenti/hrana/doniranje hran e/Program $\% 20$ za $\% 20$ provedbu $\% 20$ Plana $\% 20$ sprje $\% C 4 \% 8$ Davanja $\% 20 \mathrm{i} \% 20$ s 
manjenja\%20nastajanja\%20otpada\%20od\%20hrane\%20RH\%202019.\%20\%202022..pdf

38. Quested, T.E., Marsh, E., Stunell, D., Parry, A.D. (2013). Spaghetti soup: the complex world of food waste behaviours. Resources, Conservation and Recycling, 79, 43-51. DOI: 10.1016/j.resconrec.2013.04.011

39. Royte, E. (2016). Ne bacaj, ne gladuj. National Geographic Hrvatska, 18-39.

40. Stávková J., Prudilová H., Toufarová Z., Nagyová L. (2007). Factors influencing the consumer behaviour when buying food. Agricultural Economics - Czech, 53(6), 349-353.

41. Stangherlin, I., de Barcellos, M. (2018). Drivers and barriers to food waste reduction. British Food Journal, 120(10), 2364-2387. https://doi.org/10.1108/BFJ-12-2017-0726

42. Svržnjak, K., Kantar, S., Jerčinović, S., Gajdić, D. (2018). Analiza stanja u poljoprivredno-prehrambenom sektoru Koprivničko-križevačke i Međimurske županije u cilju osnivanja kratkih lanaca opskrbe (Analysis of the situation in the agri-food sector of the Koprivnica-Križevci and Međimurje counties in order to establish short supply chains), Working paper, Visoko gospodarsko učilište u Križevcima (Križevci College of Agriculture)

43. Šundov, M., Gajdić, D. (2019). Eco-distribution centers of agricultural products in the function of sustainable development of urban centers. $45^{\text {th }}$ International Scientific Conference on Economic and Social Development - XIX International Social Congress (ISC 2019), Moscow, 17-18 October 2019, 414423. Available at: https://www.esdconference.com/upload/book of abstracts/Book of Abstracts esdMoscow201 9 Online.pdf

44. Ubrežiová, I., Horská, E., Moravčíková, K., Ubrežiová, A. (2015). Glocalization and local alternative economic systems: The case of the Slovak Republic. Proceedings of the $7^{\text {th }}$ International Scientific Conference Rural Development 2015, Ed. Raupelienè, A., 1-6. DOI: http://doi.org/10.15544/ RD.2015.081

45. Zhong, R., Xu, X., Wang, L. (2017). Food supply chain management: systems, implementations, and future research. Industrial Management \& Data Systems, 117(9), 2085-2114. DOI 10.1108/IMDS-09-2016-0391

46. Zoll, F., Specht, K., Opitz, I., Siebert, R., Piorr, A., Zasada, I. (2018). Individual choice or collective action? Exploring consumer motives for participating in alternative food networks. International Journal of Consumer Studies, 42(1), 101-110., https://doi.org/10.1111/ijcs.12405 


\title{
EKO-DISTRIBUCIJSKI CENTRI POLJOPRIVREDNO-PREHRAMBENIH PROIZVODA U FUNKCIJI POTROŠAČKOG POTENCIJALA URBANIH SREDIŠTA
}

\author{
Marko Šundov, Dušanka Gajdić \& Kristina Petljak
}

\section{Sažetak}

Prostorna ekspanzija i povećanje broja gradova pretvara ih u neuralgične točke lanca opskrbe hranom. Zbog svoje strukture i brzine životnih procesa, hrana se u urbana središta doprema putem konvencionalnih opskrbnih lanaca te stanovništvo pretvara u izuzetno ovisne potrošače (zbog nepostojanja uvjeta samoopskrbe hranom). Zato strateški razvoj gradova zahtijeva održivo razmišljanje i rasuđivanje kada je riječ o opskrbi hranom. Jedno od mogućih rješenja za kontinuiranu i održivu opskrbu hranom urbanog stanovništva je razvoj eko distribucijskih centara poljoprivredno-prehrambenih proizvoda. Primjenom ovog modela mogu se postići brojni učinci; razvija se ruralno okruženje gradova čime se smanjuje pritisak priljeva stanovništva; osiguravanje opskrbe svježom, visokokvalitetnom hranom u dovoljnim količinama za cijelo stanovništvo; održivo se upravlja otpadom nastalim u procesima distribucije $i$ uporabe hrane. Upravljanje tokom kratkog poljoprivredno-prehrambenog lanca, tj. razvojem vlastitih proizvodno-potrošačkih kapaciteta omogućava se značajno smanjenje ovisnosti o konvencionalnim lancima istovremeno se stvaraju preduvjeti kontrole proizvodnje $i$ zbrinjavanja otpada unutar poljoprivredno-prehrambenih opskrbnih lanaca. Stoga se $u$ ovom radu analizira potrošački potencijal urbanog središta kao temeljne odrednice $u$ projektiranju $i$ implementiranju eko-distribucijskih centara za poljoprivrednoprehrambene proizvode. Empirijsko istraživanje potrošačkog potencijala u urbanim središtima provedeno je uz pomoć dva komunalna poduzeća u gradu Splitu, u 20 stambenih zgrada, a u istraživanju je sudjelovalo 148 stanara.

Ključne riječi: eko-distribucijski centar, kratki poljoprivredno-prehrambeni lanci, urbana središta, potrošački potencijal, empirijsko istraživanje. 